\title{
UDOSTĘPNIANIE I PUBLIKOWANIE WIZERUNKU NASCITURUSA, NOWORODKA I MAŁEGO DZIECKA W ŚWIETLE ZASADY DOBRA DZIECKA
}

Wizerunek człowieka jest jego dobrem osobistym ${ }^{1}$. Ustawodawca w art. 23 k.c. przyjmuje, że wizerunkowi człowieka, jako wysoko cenionej wartości (zaliczanej właśnie do kategorii dóbr osobistych), zapewnić należy ochronę prawa cywilnego, i to niezależnie od ochrony przewidzianej w innych przepisach $^{2}$. Regulacja ta obejmuje wszystkie osoby fizyczne niezależnie od cech i właściwości, które je charakteryzuja w obrocie cywilnoprawnym. Bez znaczenia dla zapewnienia ochrony z zakresu dóbr osobistych pozostaje zatem fakt przyznania osobie pełnego (czy choćby ograniczonego) zakresu zdolności do czynności prawnych, jak również fakt nabycia cechy świadomości naruszenia jej wizerunku. Ochrona wizerunku człowieka zaczyna, wraz z rozwojem i ulepszaniem nowoczesnych technologii, nabierać innego niż dotychczas tradycyjnie pojmowanego znaczenia. W związku z coraz bardziej zaawansowana technika pozwalająca na pokazywanie i utrwalanie wizerunku człowieka jeszcze przed jego urodzeniem pojawia się także problem zakresu dopuszczalności wykorzystania i publikowania wizerunku nasciturusa oraz bardzo małego dziecka.

Przedmiotem niniejszego tekstu będzie zbadanie zagadnienia dopuszczalności posługiwania się wizerunkiem małego dziecka oraz dopuszczalności publikowania tego wizerunku w taki sposób, by działania te nie godziły w zasadę dobra dziecka. Celem pozostaje udzielenie odpowiedzi na pytanie, czy wyrażenie przez przedstawiciela ustawowego zgody na publikację wizerunku małego dziecka, w szczególności noworodka i niemowlęcia, może być postrzegane jako działanie sprzeczne z dobrem dziecka. Zagadnienie to nie było dotąd przedmiotem szczegółowych analiz w doktrynie prawa cywilnego. Problem swego czasu podjęła E. Ferenc-Szydełko, jednakże sformułowane przez autorkę wnioski nie dają jednoznacznej odpowiedzi na pytanie o zakres

${ }^{1}$ E. Wojnicka, Prawo do wizerunku w ustawodawstwie polskim, Zeszyty Naukowe Uniwersytetu Jagiellońskiego. Prace z Wynalazczości i Ochrony Własności Intelektualnej 1990, z. 56, s. 107; P. Księżak, Komentarz do art. 23 kodeksu cywilnego, w: M. Pyziak-Szafnicka (red.), Kodeks cywilny. Część ogólna. Komentarz, Warszawa 2009, wersja LEX/OMEGA (35/2009).

${ }^{2}$ Por. w szczególności art. 81 ustawy o prawie autorskim i prawach pokrewnych (t.jedn.: Dz. U. 2006, Nr 90, poz. 631 ze zm.; dalej jako: Prawo autorskie); na ten temat A. Matlak, Cywilnoprawna ochrona wizerunku, „Kwartalnik Prawa Prywatnego” 2004, z. 2; M. Pazdan, w: K. Pietrzykowski (red.), Kodeks cywilny. Komentarz, Warszawa 2004, s. 84 i n.; A. Cisek, P. Machnikowski, w: E. Gniewek, P. Machnikowski (red.), Kodeks cywilny. Komentarz, wyd. 5, Warszawa 2013, s. 58 i n.; wyrok Sądu Apelacyjnego w Warszawie z 19 kwietnia 2000 r., I ACa 1455/99, OSA 2001, nr 5, poz. 27. 
i konieczność ochrony wizerunku małego dziecka i nasciturusa ${ }^{3}$. Wydaje się jednak, że zagadnienie będzie z czasem wymagało uwagi ustawodawcy i przedstawicieli nauki prawa z kilku ważkich powodów. Po pierwsze, z każdym rokiem rośnie zakres dopuszczalnych interwencji medycznych in utero $\mathrm{w}$ stosunku do płodu, gdy znajduje się on jeszcze w łonie matki, czyli kobiety ciężarnej. Interwencje te wykorzystują obrazowanie w czasie rzeczywistym. Już nie tylko techniki ultrasonograficzne (USG), lecz także rezonans magnetyczny pozwalaja obserwować nasciturusa na monitorze i utrwalać na zdjęciu czy w postaci filmu obraz zawierający rysy dziecka poczętego, a często też jego ruchy i gesty. W tym zakresie pojawia się pytanie, które trafnie stawia E. Ferenc-Szydełko, czy można tu mówić o wizerunku nasciturusa. Autorka argumentuje, że wprawdzie „,wykonane w ten sposób wizerunki nie różnią się w sposób umożliwiający łatwą identyfikację nasciturusa. Ale dla lekarza - specjalisty są zindywidualizowane, w pewnym stopniu rozpoznawalne" ${ }^{4}$. Można przyjąc tego rodzaju argumentację, jednakże z pewnymi zastrzeżeniami, o których będzie mowa $\mathrm{w}$ toku dalszych rozważań.

Po drugie, coraz powszechniej we współczesnych społeczeństwach stosuje się środki komunikacji na odległość oraz uczestniczy w życiu tzw. portali społecznościowych (np. Facebook ${ }^{5}$ ), w których umieszcza się własne fotografie i fotografie członków rodziny, filmy czy redaguje opisy odnoszące się do bieżących spraw uczestnika portalu. Często na profilach uczestników portali społecznościowych zamieszczane są także zdjęcia noworodków czy małych dzieci. Można oczywiście wstępnie przyjąć, że jeśli zdjęcie zostaje zamieszczone na profilu społecznościowym przez przedstawiciela ustawowego małoletniego dziecka, to ten pierwszy występuje jako podmiot wyrażający zgodę na naruszenie wizerunku dziecka pozostającego pod jego władza, zatem właściwie problem prawny nie powstaje. Takie założenie jest chyba jednak nazbyt pochopne. Trzeba się bowiem zastanowić nad następującymi kwestiami: Czy $\mathrm{w}$ istocie dochodzi do naruszenia wizerunku małoletniego dziecka przez zamieszczenie zdjęcia czy filmu w portalu społecznościowym? Dalej, czy tak samo należałoby traktować ewentualne przesłanie e-mailem zdjęć lub filmów oraz czy podejmujący tego rodzaju działania rodzic (przedstawiciel ustawowy) działa zgodnie z zasadą dobra dziecka i w najlepiej pojętym jego interesie? ${ }^{6} \mathrm{Na}$ koniec należy rozważyć, czy sprawa naruszenia wizerunku dziecka (jeżeliby przyjąć jego istnienie) mieści się w zakresie zwykłych, czy istotnych spraw dziecka.

Udzielając odpowiedzi na powyższe pytania $\mathrm{w}$ zakresie dopuszczalności naruszenia wizerunku, w pierwszej kolejności, nasciturusa, należy zauważyć, że istota problemu kryje się $\mathrm{w}$ zakresie zdolności prawnej tego podmiotu. Moje wcześniejsze badania skłaniaja mnie do zaakceptowania następujących

${ }^{3}$ E. Ferenc-Szydełko, Wizerunek dziecka jako dobro prawnie chronione - wybrane zagadnienia, w: M. Andrzejewski et al. (red.), Księga Jubileuszowa Profesora Tadeusza Smyczyńskiego, Toruń 2008, s. $42-43$.

${ }^{4}$ Ibidem, s. 43.

5 Por. www.facebook.com.

${ }^{6} \mathrm{Na}$ temat dobra dziecka zob. np. W. Stojanowska, Rozwód a dobro dziecka, Warszawa 1979, s. 27; T. Sokołowski, Prawo rodzinne, Poznań 2006, s. 123. 
wniosków ${ }^{7}$. Wydaje się, że nasciturusowi przyznać należy pewien zakres ogólnej i bezwzględnej zdolności prawnej niezależny od warunkowego przyznania zakresu zdolności w przepisach k.c. czy k.r.o. ${ }^{8}$ Wydaje się, że przyjąć należy bezwzględny charakter zdolności prawnej dziecka poczętego w zakresie ochrony dóbr osobistych. Podstaw trafności prezentowanej wyżej tezy, uznającej bezwzględny charakter zdolności w zakresie ochrony integralności fizycznej i psychicznej dziecka poczętego, doszukiwać się można w przepisach art. 23 i 24 k.c. ${ }^{9}$ Ustawodawca przyjmuje tam, że dobra osobiste człowieka przykładowo wymienione $\mathrm{w}$ treści przepisu pozostaja pod ochrona prawa cywilnego. Nie sposób oczywiście rozstrzygnąć, czy ustawodawca, używając w treści przepisu art. 23 k.c. określenia „,człowiek”, a w art. 24 k.c. - „ten, czyje dobro osobiste zostaje zagrożone", zamierzał oddzielić ochronę przyznawaną przez prawo cywilne od wymogu formalnej zdolności prawnej, czy też przez odejście od użycia określenia „osoba fizyczna” (co jednoznacznie łączyłoby zakres ochrony z osobami już urodzonymi) zdecydował się nadać zdolność prawną w zakresie ochrony dóbr osobistych niezależnie od ochrony udzielanej w pozostałych wypadkach w prawie cywilnym. Jednocześnie powołanie się na argumentum ad rubrica i umiejscowienie przepisu w dziale I: „Osoby fizyczne” księgi I Kodeksu cywilnego zdaje się jednoznacznie przesądzać intencje ustawodawcy.

$\mathrm{Z}$ drugiej zaś strony nieposłużenie się $\mathrm{w}$ treści wspomnianych przepisów, niejako naturalnie nasuwającym się określeniem podmiotu ochrony w postaci osoby fizycznej może skłaniać proces wykładni w kierunku uzasadnienia swoistego wyjątku, którego chciał dokonać ustawodawca, a przez użycie określenia ,człowiek” i „ten, czyje dobro osobiste zostaje zagrożone” zdecydował się na ochronę dóbr osobistych wszystkich ludzi, zatem także dziecka poczętego.

Trzeba jednak zauważyć, że wypowiedzi doktryny prawa cywilnego w tym zakresie nie sa jednoznaczne. Nie sposób chyba dalej bronić poglądu, iż „zdolność prawna (art. 8) przysługująca każdemu człowiekowi od urodzenia obejmuje ochronę jego dóbr osobistych", a jednocześnie przyznawać, że dobra osobiste dotyczą człowieka jako ,,istoty ludzkiej w sensie uniwersalnym”, i uznawać, iż dziecko poczęte ma prawo do zachowania zdolności fizycznej i psychicznej i z tego o względu przysługuje mu ochrona z art. 23 i 24 k.c. ${ }^{10}$

7 J. Haberko, Cywilnoprawna ochrona dziecka poczętego a stosowanie procedur medycznych, Warszawa 2010, passim.

8 B. Ziemianin, Z. Kuniewicz, Prawo cywilne. Część ogólna, Poznań 2007, s. 75.

${ }^{9}$ R. Majda twierdzi, że ochrona dobra osobistego dziecka poczętego aktualizuje się z chwilą urodzenia, gdyż dopiero urodzonemu dziecku przysługiwać będą prawa chroniące te dobra. Jak realizować ochronę dobra osobistego w postaci zdrowia lub życia dziecka poczętego w sytuacji zagrożenia tych dóbr w okresie prenatalnym, autor nie wyjaśnia, przyjmując, że po urodzeniu dziecko (odpowiednio reprezentowane) będzie mogło wystąpić z roszczeniami chroniącymi dobra osobiste, które zostały naruszone przed urodzeniem. Autor nie udziela odpowiedzi na kluczowe pytanie: Jak postąpić, jeśli naruszenie dobra osobistego dziecka poczętego okaże się na tyle ciężkie, że uniemożliwi mu realizację uprawnień odszkodowawczych, gdyż dziecko po prostu się nie urodzi żywe? R. Majda, Komentarz do art. 8 k.c., w: M. Pyziak-Szafnicka (red.), Kodeks cywilny. Czéść ogólna. Komentarz, Warszawa 2009, wersja Lex/Omega (35/2009).

${ }^{10}$ K. Piasecki, w: Z. Gordon, J. Łopuski, M. Nesterowicz, K. Piasecki, A. Rembieński, L. Stecki, J. Winiarz, Kodeks cywilny z Komentarzem, J. Winiarz (red.), wyd. 2 zmienione, t. 1, Warszawa 1989, 
$\mathrm{W}$ nowszych opiniach doktryna zajmuje podobne stanowisko ${ }^{11}$. Jednocześnie uznaje się obecnie, że dziecko poczęte ma jednak prawo do zachowania integralności fizycznej i psychicznej i dlatego przysługuje mu ochrona z zakresu dóbr osobistych z art. 23 i 24 k.c. ${ }^{12}$

Pojawia się zatem pytanie, czy sa takie dobra osobiste, których naruszenie może nastąpić $\mathrm{w}$ fazie życia prenatalnego człowieka i które przez fakt możliwości naruszenia wymagają ochrony ze strony prawa. Wydaje się, że oprócz życia i zdrowia właśnie wizerunek człowieka mógłby zostać zakwalifikowany do kategorii tego rodzaju dóbr osobistych ${ }^{13}$. Można bowiem posłużyć się obrazem człowieka dostrzeganym na monitorze komputera, co więcej, utrwalić ten wizerunek i wykorzystać następnie w różnych celach. W tym miejscu pojawia się jednak konieczność udzielenia odpowiedzi na pytanie, czy obraz nasciturusa utrwalony na monitorze komputera widziany przez lekarza w obrazie USG czy rezonansie magnetycznym może być postrzegany jako wizerunek w cywilnoprawnym aspekcie odpowiadajacym definicji wizerunku. Tu celowy wydaje się powrót do rozważań E. Ferenc-Szydełko, która twierdzi, że wykonywane obrazy nie różnią się w sposób znaczny i nie pozwalają postronnemu obserwatorowi na różnicowanie dzieci widzianych w obrazie USG czy rezonansie magnetycznym ${ }^{14}$. Jednakże dla profesjonalisty moga stanowić przesłanki rozróżnienia. Pojawia się zatem konieczność udzielenia odpowiedzi na pytanie, czy widziany w USG bądź rezonansie magnetycznym obraz człowieka stanowi jego wizerunek w cywilnoprawnym ujęciu tego terminu.

W doktrynie prawa cywilnego zwykło się przez pojęcie wizerunku rozumieć utrwalone fotografia rysy twarzy, głowę, jak i całą postać, indywidualizujące osobę $^{15}$. Na wizerunek $\mathrm{w}$ ujęciu prawa cywilnego składają się zatem dostrzegalne, fizyczne cechy człowieka, tworzące jego wygląd i pozwalające na identyfikację osoby wśród innych ludzi ${ }^{16}$.

W tym kontekście kluczowa wydaje się odpowiedź na pytanie o indywidualizację i rozpoznawalność wizerunku dziecka poczętego. Jak zauważono, dla

s. 25 i 37. Autor powtórzył swoje stanowisko także w Komentarzu z 2003 r. zob. K. Piasecki, Kodeks cywilny, Komentarze Zakamycza, Księga Pierwsza, Część ogólna, Kraków 2003, s. 106.

11 T. Sokołowski, w: A. Kidyba (red.), Kodeks cywilny. Komentarz, Warszawa 2009, s. 58.

12 Tak, aczkolwiek bez uzasadnienia, K. Piasecki, Komentarz..., op. cit.

${ }^{13}$ Szerzej J. Haberko, Wyrzadzenie szkody prenatalnej w kontekście zdolności prawnej dziecka poczętego, w: M. Nesterowicz (red.), Czyny niedozwolone w prawie polskim i prawie porównawczym Materiaty IV Ogólnopolskiego Zjazdu Cywilistów, Warszawa 2012, s. 163-179.

${ }^{14}$ Zob. Z. Polska, Wewnatrzmaciczna chirurgia ptodu, „Ogólnopolski Przegląd Medyczny” 2005, nr 12 , s. 38.

${ }^{15}$ P. Księżak, Komentarz..., op. cit.; J. Barta, R. Markiewicz, Wokót prawa do wizerunku, Zeszyty Naukowe Uniwersytetu Jagiellońskiego. Prace z Wynalazczości i Ochrony Własności Intelektualnej 2002, z. 80, s. 12; Z. Radwański, A. Olejniczak, Prawo cywilne - część ogólna, wyd. 11, Warszawa 2011, s. 163.

${ }^{16} \mathrm{~W}$ orzecznictwie powołano także szerszą koncepcję pojęcia wizerunku, przyjmując, że z dobrem osobistym w postaci wizerunku ,,mamy do czynienia również wówczas, gdy ujawnione na fotografii cechy pozwalają na identyfikację przedstawionej na niej osoby, co następuje z wykorzystaniem okoliczności pozwalających na wywołanie skojarzenia z określoną osobą. Identyfikacja następuje tu zarówno w nawiązaniu do podobizny, jak i do innych cech. Taka wykładnia pojęcia wizerunku w świetle orzecznictwa Sądu Najwyższego nie może być uznana za nieprawidłowa”. Por. wyrok Sądu Najwyższego z 27 lutego 2003 r., I V CKN 1819/00, OSP 2004, nr 6, poz. 75; wyrok Sądu Apelacyjnego w Warszawie z 16 kwietnia 2010 r., I ACa 1100/09, Lex, nr 1110229. 
postronnego obserwatora - laika niemającego wiedzy medycznej - wszystkie obrazy pozyskiwane w czasie badania ultrasonograficznego pozostaja do siebie podobne, co więcej, niekoniecznie mogą być przez niego rozumiane, odczytane czy właściwie interpretowane. Nie dają przez to możliwości przyjęcia, że uzyskiwany w obrazie USG ,,wizerunek” pozostaje rozpoznawalny dla wszystkich. Nie to jednak stanowi o istocie cechy wizerunku. Wizerunek człowieka należy bowiem postrzegać $\mathrm{w}$ kontekście przyznanej każdemu człowiekowi, a zatem i dziecku poczętemu, godności. W świetle art. 30 Konstytucji RP przyrodzona i niezbywalna godność człowieka stanowi źródło wolności i praw człowieka i obywatela ${ }^{17}$. Jest ona nienaruszalna, a jej poszanowanie i ochrona jest obowiązkiem władz publicznych. W tym kontekście naruszenie pozyskanego w obrazie USG wizerunku dziecka poczętego nabiera niewątpliwie innego znaczenia. Nie sam fakt rozpoznawalności, w mojej ocenie, będzie stanowił o tym, czy narusza się wizerunek dziecka poczętego czy nie, ale to czy działania wykorzystujące uzyskany obraz godzą w wartości uznane przez ustawodawcę, takie jak godność dziecka poczętego jako człowieka. Innymi słowy: Czy pobieraniem i publikowaniem takiego obrazu nie godzi się w godność człowieka? ${ }^{18}$ Pojawia się bowiem pytanie, czy człowiek wyraziłby zgodę na to, by jego obraz był powielany, udostępniany i rozpowszechniany innym bez zgody własnej, ewentualnie zgody przedstawiciela ustawowego.

Tu pojawia się kolejna wątpliwość, która wcześniej stanowiła przedmiot moich rozważań, a mianowicie: zakres dopuszczalnych działań rodzica jako przedstawiciela ustawowego dziecka poczętego ${ }^{19}$. Jeżeliby przyjąć przychylne nasciturusowi stanowisko i dopuścić wyrażanie zgody na udostępnienie wizerunku przez rodziców (np. w sytuacji posłużenia się uzyskanym obrazem przez lekarza w trakcie konferencji naukowej dla przedstawienia studentom medycyny przypadku medycznego), zachowane powinny zostać wszelkie zasady wykorzystania danych pacjenta. Mowa tu o art. 40 ustawy o zawodach lekarza i lekarza dentysty ${ }^{20}$. W świetle tego przepisu lekarz ma obowiązek zachowania

17 Por. także F. Longchamps de Bérier, Za poczatek życia można uznać tylko dwa momenty: poczęcie albo urodzenie, „Rzeczpospolita” z 9 stycznia 2007 r.; T. Smyczyński, Opinia prawna o poselskim projekcie zmiany (art. 38) Konstytucji Rzeczypospolitej Polskiej, w: Przed pierwszym czytaniem, Wydawnictwo Biura Analiz Sejmowych 2007, nr 3, s. 17 i n.; J. Jabłońska, Prawo do informacyjnego samostanowienia $i$ jego konkretyzacja $w$ relacji pacjent - lekarz, w: J. Haberko, R. D. Kocyłowski, B. Pawelczyk (red.), Lege artis - Problemy prawa medycznego, Poznań 2008, s. 65.

${ }^{18}$ Stanowisko takie zajął Sąd Apelacyjny w Warszawie, przyjmując, że ,,analiza samych zdjęć nie prowadzi do identyfikacji powódki. Dokonać tego można było łącznie z informacją zawartą w artykule, tak zresztą identyfikacji powódki dokonali świadkowie zeznający w sprawie [...] nie należy stawiać znaku równości pomiędzy wizerunkiem a rozpoznawalnością. Elementy postaci powódki, które wskazywali świadkowie, były niewystarczające, aby mówić o wizerunku. Zatem można podzielić stanowisko skarżącego, że nie doszło do naruszenia prawa do wizerunku, czyli wizerunku w znaczeniu podobizny. Jednakże możliwość identyfikacji w powiązaniu z treścią artykułu prowadziła do tzw. rozpoznawalności, stąd więc istniały podstawy do przyjęcia, że przez publikację zdjęć doszło do naruszenia pozostałych dóbr osobistych wskazanych przez powódkę, to jest czci, godności, strefy intymnej”. Por. wyrok Sądu Apelacyjnego w Warszawie z 16 kwietnia 2010 r., I ACa 1100/09, Lex, nr 1110229.

19 Czytelnika pragnącego zgłębić materię dopuszczalnych działań rodziców w stosunku do dziecka poczętego wypada odesłać do mojej publikacji w tym zakresie: J. Haberko, Cywilnoprawna..., rozdz. II: Rodzice a dziecko poczęte.

${ }^{20}$ Ustawa z 5 grudnia 1996 r. o zawodach lekarza i lekarza dentysty (t.jedn.: Dz. U. 2008, Nr 136, poz. 857 ze zm.). 
$\mathrm{w}$ tajemnicy informacji związanych $\mathrm{z}$ pacjentem, a uzyskanych $\mathrm{w}$ związku $\mathrm{z}$ wykonywaniem zawodu ${ }^{21}$. Jeśli przedstawiciel ustawowy wyraziłby zgodę na posłużenie się zdjęciem nasciturusa, lekarz i tak pozostawałby związany art. 40 ust. 4 u.z.l., w świetle którego nie może on podać do publicznej wiadomości danych umożliwiających identyfikację pacjenta bez jego zgody (tu chodzić będzie o zgodę przedstawiciela ustawowego). Oczywisty $\mathrm{w}$ tym zakresie pozostaje fakt, że nie można mówić o identyfikacji samego nasciturusa, ale ze względu na wyjątkowe środowisko, w którym on się znajduje i wzrasta, może być mowa o naruszeniu jego dóbr osobistych przez identyfikacje jego matki. Możliwy do wyobrażenia pozostaje bowiem taki sposób naruszenia, w którym lekarz podaje dane kobiety ciężarnej, podpisując obraz czy zdjęcie w następujący sposób: ,pacjenci: Anna Nowak ${ }^{22}$, lat... oraz płód płci męskiej w 26 t.c., $\mathrm{z}$ widocznym na obrazie schorzeniem określonego typu". Nie ulega dla mnie wątpliwości, że tego rodzaju użycie danych (niekiedy i wizerunku) kobiety ciężarnej oraz wizerunku rozwijającego się w jej organizmie dziecka narusza także dobra osobiste i godzi w godność tego ostatniego. Sam fakt, że wizerunek naruszony został $\mathrm{w}$ trakcie życia prenatalnego, dla istoty zagadnienia pozostaje bez znaczenia. Pozwala bowiem na wykorzystanie wizerunku także po zakończeniu tego okresu rozwoju człowieka.

Posłużenie się w sposób niezgodny z prawem wizerunkiem dziecka poczętego przez lekarza podlega profesjonalnej ocenie wykonywania zawodu i takiej odpowiedzialności za naruszenie zasad deontologii. Wydaje się także, że zdarzać się będzie stosunkowo rzadko. Nieco więcej wątpliwości budzą dwie inne sytuacje, mianowicie wykorzystanie zdjęć z obrazu USG przez lekarza bez zgody rodziców, ale w taki sposób, który uniemożliwia identyfikację zarówno ciężarnej, jak i dziecka poczętego, oraz wykorzystanie zdjęć ultrasonograficznych przez samych rodziców.

Wykorzystanie przez lekarza wizerunku nasciturusa w sposób uniemożliwiający identyfikację dziecka przez osoby bez wykształcenia medycznego dokonane bez wyrażenia stanowiska przedstawicieli ustawowych niewątpliwie narusza dobre obyczaje, ale nie godzi chyba jednak de lege lata $\mathrm{w}$ zasady wykonywania zawodu lekarza, jeżeli identyfikacja obiektywnie nie jest możliwa. Nie oznacza to jednak, że w pewnych sytuacjach możliwa nie będzie. Może chodzić np. o przypadek zdiagnozowanej u nasciturusa wyjątkowo rzadkiej choroby, o której rodzice poinformowali innych za pośrednictwem środków masowego przekazu dla uzyskania funduszy na leczenie schorzenia ich dziecka. W takim wypadku posłużenie się przez lekarza obrazem, na którym widoczny będzie nasciturus w stanie choroby, pozwala już założyć możliwość jego identyfikacji i przez to rozpoznawalnośćc ${ }^{23}$. Jednocześnie nie sposób wyłączyć de lege

${ }^{21}$ Zob. M. Safjan, Problemy prawne tajemnicy lekarskiej, „Kwartalnik Prawa Prywatnego” 1995, z. 1, s. 11 i n.; A. Huk, Tajemnica zawodowa lekarza, „Prokuratura i Prawo” 2001, nr 6, s. 72; B. Kunicka-Michalska, Ochrona tajemnicy zawodowej w polskim prawie karnym, Warszawa 1972, s. 21; J. Haberko, R. Kocyłowski, Szczególna postać tajemnicy lekarskiej w przypadku stosowania technik medycznie wspomaganej prokreacji, „Prawo i Medycyna” 2006, nr 23, s. 23 i n.

${ }^{22}$ Użyto powszechnie występującego w kraju złożenia imion i nazwisk bez odniesienia do konkretnej osoby.

${ }^{23}$ Por. wyrok Sądu Apelacyjnego w Warszawie z 16 kwietnia 2010 r., I ACa 1100/09, Lex, nr 1110229. 
ferenda konieczności interwencji ustawodawcy w sytuacji doskonalenia środków technicznych pozwalających na obserwowanie i diagnozowanie dziecka poczętego. Chyba w najbliższym czasie trudno oczekiwać, by dzieci widziane w obrazie USG wyglądały jak ,na zdjęciach z wakacji”, jednakże naiwnością byłoby założenie, że techniki obrazowania ultrasonograficznego czy rezonans magnetyczny nie będą doskonalone dla uzyskiwania jeszcze lepszych sposobów obrazowania.

Drugi problem jest zdecydowanie bardziej złożony. Samo wykorzystanie przez rodziców zdjęć czy filmów pozyskanych w trakcie badania lekarskiego nie podlega bowiem ocenie profesjonalnej wykonywania zawodu, tak jak miało to miejsce w wypadku lekarza. Można oczywiście przyjąć, że rodzice mogą podjąć $\mathrm{w}$ zasadzie niczym nieograniczone działania odnoszące się do pozyskanego w badaniu ultrasonograficznym obrazu. Nierzadko się zdarza, że obraz ten, a także utrwalony $\mathrm{np}$. na płycie CD film sa przedmiotem pokazu w gronie rodzinnym i bliskich znajomych. Zdarza się niekiedy także, że obraz ten jest przez rodziców oczekujących dziecka rozsyłany za pomoca środków porozumiewania się na odległość (e-mail) lub publikowany na profilach portali społecznościowych. Prawo nie udziela jednoznacznych odpowiedzi na temat dopuszczalności bądź nie tego rodzaju działań podejmowanych przez rodziców. Przyjmując znów przychylne nasciturusowi stanowisko, w świetle którego rodzice pozostawaliby przedstawicielami ustawowymi dziecka poczętego, należałoby założyć, że wszelkie ich działania podejmowane są dla dobra dziecka. Zatem rodzice publikując bądź przesyłając obraz (np. dziadkom), manifestuja swoje oczekiwanie, przywiązanie i miłość do mającego się narodzić potomka ${ }^{24}$. W tym zakresie działania rodziców nie moga być ocenione negatywnie, o ile rodzice udostępniając obraz swojego dziecka, udostępniaja go osobom, co do których maja pewność, że osoby te (np. dziadkowie) nie podejmą działań sprzecznych $\mathrm{z}$ interesem dziecka ani teraz, ani w przyszłości. Rodzic $\mathrm{w}$ tym zakresie, oprócz poddania się normom prawnym, powinien bowiem zachować daleko posunięty zdrowy rozsądek i umiar, a przede wszystkim przewidywać, co w przyszłości może się stać z obrazami dziecka przesyłanymi innym osobom. Rzecz jasna jeżeli osoba, której przesłano zdjęcie lub udostępniono film $\mathrm{w}$ portalu społecznościowym podjęłaby działania sprzeczne $\mathrm{z}$ wola rodziców (można wyobrazić sobie wykorzystanie zdjęcia w celach komercyjnych), należałoby raczej de lege ferenda niż de lege lata rozważyć odpowiedzialność za naruszenie dóbr osobistych dziecka poczętego.

W tym samym kontekście pojawia się kwestia udostępniania i publikowania zdjęć małych dzieci, a zwłaszcza noworodków. W tym aspekcie nie pozostawia wątpliwości kompetencja rodziców do wyrażenia zgody na udostępnienie i publikowanie zdjęcia ich dziecka. W wypadku bardzo małych dzieci - niemowląt i noworodków pojawia się podobnie jak w wypadku nasciturusa pytanie o zakres rozpoznawalności i pewnych cech osobniczych charakteryzujących podmiot, którego wizerunek mógłby zostać naruszony. Doskonale obrazuje to przywołany przez E. Ferenc-Szydełko przykład głośnej sprawy pielęgniarek,

${ }^{24}$ Zob. na temat rodzice-dziadkowie np. J. Haberko, Dziadkowie-wnuki. Osobista więź prawnorodzinna i relacja prawnospadkowa, „Ruch Prawniczy, Ekonomiczny i Socjologiczny” 2012, z. 3, passim. 
które na oddziale neonatologicznym podejmowały działania tego rodzaju, że ważące nie więcej niż kilogram noworodki wkładały do kieszeni fartucha. W publikacjach prasowych zasłonięto oczy pielęgniarek bądź ukazano je w sposób niepozwalający na identyfikację, podczas gdy dzieci pokazane zostały w sposób umożliwiający ich pełną identyfikację $e^{25}$. W dyskusji powoływano następnie ten argument, że dziecko na wczesnym etapie swojego rozwoju nie jest jeszcze na tyle rozwinięte fizycznie i nie nabiera charakterystycznych cech, nie dysponuje szczególnymi rysami twarzy, szczególną mimiką, by cechy te pozwalały na nieopatrzoną ryzykiem błędu identyfikację dziecka.

Stanowisko sprowadzało się $\mathrm{w}$ istocie do jednego argumentu, mianowicie: wszystkie dzieci w okresie noworodkowym sa do siebie bardzo podobne, a cech osobniczych pozwalających na ich identyfikację nabywają dopiero później. Można oczywiście bronić tego stanowiska i takiego sposobu argumentacji. Argumentem na poparcie tego poglądu ma być to, że wszystkie małe dzieci $\mathrm{w}$ okresie noworodkowym są do siebie podobne, skoro w placówkach służby zdrowia opatruje się je tasiemkami z imieniem i nazwiskiem dziecka, niekiedy jest to nawet imię $\mathrm{i}$ nazwisko matki wraz $\mathrm{z}$ data urodzenia dziecka i oznaczeniem płci ${ }^{26}$. Wydaje się jednak, że fakt, iż należy dziecku w placówce służby zdrowia założyć tasiemkę z imieniem i nazwiskiem nie może przesądzaćpo pierwsze - o jego nierozpoznawalności, a po drugie - usprawiedliwiać pozbawienia go ochrony wizerunku. Człowiek bowiem pewnych cech nabiera dopiero z czasem i wiekiem, niemniej jednak dla rodziców, dziadków czy opiekującego się noworodkiem personelu medycznego nie ma wątpliwości, że każde $\mathrm{z}$ tych dzieci jest zindywidualizowane i że każde wykazuje się pewnymi cechami charakteryzującymi i odróżniającymi je od innych nawet bardzo małych dzieci. Jeżeli przyjmuje się, że wizerunkiem są utrwalone rysy twarzy człowieka bądź cała jego postać, charakterystyczne jego cechy (kolor oczu, włosów, ich istnienie bądź ich zupełny brak, a nawet dźwięk płaczu ${ }^{27}$ ), trudno bronić tezy, iż dziecko $\mathrm{w}$ okresie noworodkowym miałoby zostać pozbawione ochrony wizerunku. Podzielam w tym zakresie także ten argument E. Ferenc-Szydełko, która konieczności ochrony wizerunku nawet bardzo małych dzieci (noworodków i niemowląt) dopatruje się w przepisach ustawy o dokumentach paszportowych ${ }^{28}$.

Należy również zauważyć, że to rodzice jako przedstawiciele ustawowi małoletniego podejmuja decyzje o udostępnieniu ewentualnie publikacji

\footnotetext{
${ }^{25}$ Dla przykładu http://wiadomosci.gazeta.pl/wiadomosci/1,114873,4100567.html.

${ }^{26}$ Od 1 stycznia 2013 r. każdy z pacjentów poddawanych diagnostyce i terapii w warunkach szpitalnych otrzymuje mocowaną na przegubie dłoni tasiemkę z kodem pacjenta niezależnie od cech fizycznych go indywidualizujących.

${ }^{27}$ Por. wyrok SA w Gdańsku z 21 czerwca 1991 r., I ACr 127/91, OSA 1992, z. 1, poz. 8; J. S. Piątowski, Ewolucja ochrony dóbr osobistych, w: E. Łętowska (red.), Tendencje rozwoju prawa cywilnego, Ossolineum 1983, s. 35 i n.; P. Księżak, Komentarz..., op. cit.

${ }^{28}$ E. Ferenc-Szydełko, Wizerunek..., s. 43; ustawa z 13 lipca 2006 r. o dokumentach paszportowych, Dz. U. 2006, Nr 143, poz. 1027 ze zm. Wprawdzie od chwili ogłoszenia drukiem tekstu E. Ferenc-Szydełko ustawa w powołanym przez autorkę art. 21 została znowelizowana, ale nadal wykładnia ustawy nie pozostawia wątpliwości co do obowiązku paszportowego noworodka. Ustawodawca uznaje konieczność zamieszczenia w paszporcie dla dziecka jego zdjęcia, uznaje zatem - tak jak chce autorka - że nawet „,portret kilkudniowego noworodka jest zindywidualizowaną wartością osobista”.
} 
wizerunku ich dziecka. Pojawia się jednak pytanie, czy wyrażenie zgody na udostępnienie wizerunku dziecka jest jego zwykła, czy istotną sprawą. I w tym zakresie udzielenie odpowiedzi na pytanie nie wydaje się jednoznaczne. $\mathrm{W}$ świetle art. $98 \S 1$ k.r.o. rodzice sa przedstawicielami ustawowymi dziecka pozostającego pod ich władzą, jeżeli zaś dziecko pozostaje pod władzą rodzicielską obojga rodziców, każde z nich może działać samodzielnie jako przedstawiciel ustawowy. Na władzę rodzicielską, co nie budzi wątpliwości przedstawicieli nauki, składa się w wypadku dziecka urodzonego jego reprezentowanie. Rodzice sa zatem umocowani do działania w cudzym imieniu, konkretnie imieniu swojego dziecka, przez co realizuja przedstawicielstwo ustawowe ${ }^{29}$. Czynność prawna dokonana przez rodziców pociąga $\mathrm{w}$ świetle art. 95 k.c. skutki prawne bezpośrednio dla dziecka. Oznacza to, że dziecko ma w sytuacji modelowej dwóch przedstawicieli ustawowych, których niezależne i samodzielne działania wiazżą dziecko.

Podzielam w omawianej materii odosobniony pogląd wyrażony w literaturze przez J. Gajdę, że samodzielność działań rodziców nie obejmuje w zakresie reprezentacji tych sytuacji, dla których ustawa wymaga zgodnego działania i wspólnego podejmowania przez nich decyzji obejmującej w świetle art. 97 $\S 2$ k.r.o. istotne sprawy dziecka ${ }^{30}$. Oznacza to, że nie tylko podejmowanie decyzji o istotnych sprawach dziecka oparte powinno być na zasadzie współdziałania rodziców, lecz także reprezentacja dziecka nie może odbywać się wyłącznie przez jednego $\mathrm{z}$ nich z pominięciem drugiego rodzica. Jeżeli ustawa wymaga decyzji co do istotnych spraw dziecka, to reprezentacja powinna odzwierciedlać także tę zasadę. Oznacza to w konsekwencji, iż rodzic niereprezentujący dziecka po wspólnym podjęciu decyzji powinien wyrazić zgodę na reprezentowanie dziecka przez drugie $\mathrm{z}$ rodzicó $\mathrm{w}^{31}$.

Odnosząc te uwagi do sytuacji udostępnienia wizerunku małego dziecka, należy zauważyć, że nie ma jednoznacznej odpowiedzi na pytanie, czy to udostępnienie, a nawet zgoda na publikowanie wizerunku, zaliczona powinna zostać do zwykłej czy istotnej sprawy dziecka. Jeżeliby przyjąć, że udostępnienie i wyrażenie zgody na publikację wizerunku małego dziecka jest jego zwykła sprawa, każde z rodziców mogłoby decydować samodzielnie, jeżeli jednak zgodę w omawianym zakresie zaliczylibyśmy do spraw istotnych dziecka, rodzice powinni o niej decydować wspólnie. Jednocześnie nie można zapominać, że każde z rodziców może samodzielnie reprezentować swoje dziecko, nawet jeżeli sprawa jest istotna sprawą dziecka ${ }^{32}$. Należy zatem udzielić odpowiedzi na pytanie, czy o udostępnieniu wizerunku dziecka innym osobom rodzice powinni

${ }^{29}$ H. Ciepła, w: K. Piasecki (red.), Kodeks rodzinny i opiekuńczy. Komentarz, wyd. 3, Warszawa 2006, s. 641.

${ }^{30}$ J. Gajda, Kodeks rodzinny i opiekuńczy. Akty stanu cywilnego. Komentarz, Warszawa 2002, s. 389. O istotnych sprawach dziecka w kontekście diagnozy i terapii M. Świderska, w: M. Nesterowicza (red.), Ustawa o prawach pacjenta i Rzeczniku Praw Pacjenta. Komentarz, Warszawa 2009, s. 169.

31 J. Gajda, Kodeks..., s. 389; M. Czarkowski, J. Różyńska, Świadoma zgoda na udziat w eksperymencie medycznym. Poradnik dla badacza, Warszawa 2008, s. 37.

${ }^{32}$ J. Ignatowicz, w: K. Pietrzykowski (red.), Kodeks rodzinny i opiekuńczy. Komentarz, Warszawa 2012, s. 885; J. Strzebinczyk, w: System prawa prywatnego, t. 12: Prawo rodzinne $i$ opiekuńcze, red. T. Smyczyński, Warszawa 2011, s. 293 i n.; T. Sokołowski, Kodeks rodzinny i opiekuńczy. Komentarz, Warszawa 2010, s. 595; J. Haberko, Cywilnoprawna..., s. 146 i n. 
decydować wspólnie, czy też każde $\mathrm{z}$ nich może decydować oddzielnie. Doświadczenie życiowe podpowiada, że w takich sytuacjach rodzice nie zawsze podejmuja działania wspólnie. Oczywiście moga przyjąć wspólnie, że nie będa udostępniać zdjęć swojego nowonarodzonego czy nieco starszego dziecka innym osobom. Wówczas naruszenie postanowienia przez którekolwiek z rodziców skutkowałoby chyba w sposób wyraźny złamaniem zasady dobra dziecka i mogłoby spotkać się z interwencją ze strony sądu opiekuńczego. Zwykle jednak w omawianym zakresie każde $\mathrm{z}$ rodziców działa samodzielnie, udostępniając zdjęcia czy filmy z wizerunkiem dziecka innym osobom. Stoję na stanowisku, że o ile można przez wzgląd na doświadczenie życiowe zaakceptować powyższe rozwiązanie, o tyle zgoda na rozpowszechnianie wizerunku dziecka w trybie art. 81 Prawa autorskiego powinna być zaliczona do istotnych praw dziecka, i przez to wymagałaby zgody obojga przedstawicieli ustawowych ${ }^{33}$.

$\mathrm{Na}$ koniec rozważyć należy, czy udostępnianie wizerunku noworodka oraz małego dziecka nie stoi w sprzeczności z zasadą dobra dziecka. Można w tym zakresie powołać pogląd, że tego rodzaju działania, jak np. przesyłanie zdjęć noworodka czy małego dziecka znajomym, znajomym znajomych czy obcym osobom godzi w godność dziecka, ponieważ uprzedmiotawia je i czyni z niego obiekt, który inni oglądają i oceniają. Niewątpliwie tak po części jest. Zwłaszcza w wypadku nowo narodzonego dziecka (czy niekiedy długo wyczekiwanego i bardzo upragnionego potomka, czasem nawet wnuka) pozostaje ono obiektem (zazwyczaj życzliwych) ocen i komentarzy ze strony członków rodziny i znajomych. Nie ulega wątpliwości, że niekiedy nowo narodzone dziecko może być oglądane i oceniane w sposób podobny do tego, w jaki ocenia się wygląd nowo nabytego przedmiotu. Czy należałoby rodzicom zakazać prawnie tego rodzaju działań? Zdecydowanie nie. Po pierwsze dlatego, że założenie prawne tego rodzaju zakazu sprowadziłoby go do zupełnego legislacyjnego absurdu. Zakaz ten byłby po prostu nieegzekwowany. Po drugie, przyjęcie powyższego stanowiska i wprowadzenie czegoś na kształt zakazu godziłoby w istotę władzy rodzicielskiej. Ustawodawca, przyznając rodzicom stosunkowo szeroki zakres pieczy i reprezentacji w stosunku do ich małoletniego dziecka, wychodzi bowiem z dwóch istotnych założeń. Po pierwsze, że to właśnie rodzice są tymi podmiotami, które chca dla dziecka jak najlepiej; a po drugie, że wszystkie ich działania jako przedstawicieli ustawowych podejmowane są zgodnie $\mathrm{z}$ zasadą dobra dziecka.

Czy zatem działania rodziców polegające na udostępnieniu wizerunku ich dziecka moga być zawsze kwalifikowane jako działania zgodne $\mathrm{z}$ interesem dziecka? Niekoniecznie, ale precyzyjna odpowiedź na tak postawione pytanie pozostaje, mimo powyższych założeń, niezwykle trudna. Wydaje się, że rodzicom czy przedstawicielom ustawowym należy zalecać umiar, a nade wszystko zdrowy rozsądek w prezentowaniu wizerunku ich dziecka innym

\footnotetext{
${ }^{33} \mathrm{Na}$ temat wizerunku w ujęciu art. 81 ustawy - Prawo autorskie zob. J. Barta et al., Komentarz do art. 81 ustawy z dnia 4 lutego 1994 r. o prawie autorskim i prawach pokrewnych, w: Ustawa o prawie autorskim $i$ prawach pokrewnych. Komentarz, Dom Wydawniczy ABC, 2001. Zob. także wyrok Sądu Okręgowego w Szczecinie z 7 września 2006 r., I C 1536/03, niepublikowany; wyrok Sądu Apelacyjnego w Warszawie z 16 kwietnia 2010 r., I ACa 1100/09, Lex, nr 1110229.
} 
osobom. Dotyczy to zwłaszcza prezentowania zdjęć i filmów samodzielnych już małych dzieci w portalach społecznościowych. Rodzice liczyć muszą się z tym, że udostępniony przez nich raz innym osobom wizerunek dziecka może trafić do rąk osób postronnych, których działania niekoniecznie będą przychylne rodzicom oraz dziecku. Można w tym zakresie wyobrazić sobie sytuację osoby, która podejmuje działania wymierzone w dobro dziecka: zwabia je, a następnie nakłania do poddania się stosunkowi cielesnemu lub innym czynnościom seksualnym ${ }^{34}$. Osoba taka, mając łatwy dostęp do portali społecznościowych, może obserwować profil rodzica, na którym ten zamieszcza zdjęcia własne i zdjęcia dziecka, opisuje sytuacje z życia rodziny, umieszcza informacje o odbytych podróżach, zamieszcza fotografie lub filmy z rodzinnych uroczystości bądź wyjazdów wakacyjnych. Dla osoby, która ma dostęp do danych osobowych rodzica i danych dziecka (zwłaszcza jego wizerunku), pozyskanie informacji o szkole, zajęciach pozalekcyjnych czy innych aktywnościach dziecka nie wydaje się szczególnie skomplikowane. Można dalej wyobrazić sobie, że taka osoba, chcąc zwabić dziecko, opowiada mu o poleceniu odbioru go ze szkoły, a żeby uwiarygodnić własną osobę, powołuje się na dane i zdjęcia zamieszczone w portalu internetowym przez któreś z rodziców. Już tylko sprawa inwencji i pomysłowości tej osoby (np. o skłonnościach pedofilskich) pozostanie pozyskanie takiego zasobu danych, by informujac dziecko o tym, jak mają na imię rodzice, gdzie rodzina była na wakacjach, jak było ubrane dziecko w czasie wycieczki na Saharze itp., zyskać jego zaufanie.

Nie mam wątpliwości, że opisana wyżej sytuacja faktyczna stanowi zagrożenie dla dziecka. Nie ulega też wątpliwości, że w razie jej zaistnienia moralną, a także cywilną odpowiedzialność za szkodę wyrządzoną dziecku ponoszą również rodzice. To oni przez własne pochopne, nieprzemyślane i nazbyt naiwne działanie, polegające na publikacji zdjęć dziecka w portalu społecznościowym, niejako zachęcili do podjęcia działań sprzecznych z zasada dobra dziecka. Sami również tę zasadę naruszyli. Oczywiście nie chodzi w tej sytuacji o konieczność kierowania ad casu zapytania do sądu opiekuńczego w sprawie udostępnienia wizerunku dziecka i np. przesłania znajomym fotografii dziecka, chodzi o to, by uświadomić rodzicom konieczność kierowania się zasada dobra dziecka w pozornie niemających prawnego znaczenia sytuacjach, takich jak podejmowanie aktywności na portalu społecznościowym. Rodzic powinien bowiem wykazać się dalekowzrocznością tego rodzaju, by zamieszczając nagie zdjęcie swojego nowo narodzonego syna czy córki przewidzieć, że to zdjęcie niekoniecznie trafi do osób życzliwych rodzicom i dziecku. Po drugie, powinien zdawać sobie sprawę, że zdjęcie to $\mathrm{w}$ portalu społecznościowym „,zacznie żyć własnym życiem”, co za kilka czy kilkanaście lat niekoniecznie może być pozytywnie postrzegane przez samo dziecko. Po trzecie wreszcie, rodzic powinien zdawać sobie sprawę, że zamieszczając zdjęcie małego dziecka, może spotkać się $\mathrm{z}$ zarzutem nieuzasadnionego naruszenia prywatności i intymności dziecka, a takie działania moga spotkać się z reakcja sądu opiekuńczego. Jeśli działania rodziców godziłyby w dobro dziecka w ten sposób, że rodzic zamieszczałby zdjęcia swojego dziecka bez ubrania bądź w pozach,

${ }^{34}$ Por. art. 200 i n. k.k. 
które mogłyby sugerować poddanie dziecka czynnościom seksualnym, bądź ośmieszałyby dziecko i godziły w jego godność, sąd opiekuńczy powinien podjąć działania dla ograniczenia władzy rodzicielskiej w trybie art. 109 k.r.o. przez wydanie odpowiednich zarządzeń.

dr hab. Joanna Haberko

Profesor Uniwersytetu im. Adama Mickiewicza w Poznaniu

\title{
AVAILABILITY AND PUBLICATION OF A PICTURE OF A NASCITURUS, A NEWBORN BABY, AN INFANT AND A CHILD IN LIGHT OF THE CHILD WELFARE PRINCIPLE
}

\author{
Summary
}

The subject of this paper as an analysis of the permissibility of using a picture of a small child and a publication of such a picture, which may only be allowed if the child welfare has been protected. An attempt is made to answer the question whether a consent granted by a representative of a state authority to publish a picture of a child, an infant, or a newborn baby in particular, may amount to an act contrary to child welfare. The deliberations of the paper include issues such as using a picture of a human being from foetal life, or parents placing a picture of their small child on a social network page. 
Copyright of Journal of Law, Economics and Sociology is the property of Faculty of Law and Administration of Adam Mickiewicz University in Poznan and its content may not be copied or emailed to multiple sites or posted to a listserv without the copyright holder's express written permission. However, users may print, download, or email articles for individual use.

Właścicielem praw autorskich do „Ruchu Prawniczego, Ekonomicznego i Socjologicznego” jest Wydział Prawa i Administracji Uniwersytetu im. Adama Mickiewicza w Poznaniu. Zawartość czasopisma nie może być kopiowana, przesyłana do innych stron internetowych bądź zamieszczana na blogach bez pisemnej zgody wydawcy. Niemniej artykuły można drukować, kopiować lub przesyłać w formie elektronicznej na własny użytek. 